\title{
Comparative Analysis of Disaster Management between Japan \& India
}

\author{
Dr. Priyanka Banerji, Ms. Nidhi Singh \\ (Assoc. Prof., DBGI, Dehradun) (Ph.D, M.Com, PGDBA, PGDCA) \\ (Assistant Prof., DBGI, Dehradun) (M.A., MBA, M.Phil., B.Ed.) \\ Comparative Analysis of Disaster Management between Japan \& India
}

\begin{abstract}
Natural Calamity is a bitter truth from which no one can escape. So many deaths, diseases, economic and social loss are few results of natural calamity. Disaster risk is on the rise all the way through the world. The economic losses and the number of people who have been affected by natural calamities have increased significantly over the past decades than the population growth, which slows down the economic growth of the affected country. The physical, social, particularly the emotional aspect and economic losses caused by these disasters are particularly more expensive for developing countries.

To minimize the damages caused by disasters, various efforts have been taken by government, society, $N G O$ 's and international communities.

Despite highest disaster preparedness by Japanese Government, on March 11, 2013, northeastern part of Japan has been severely devastated by magnitude 9 earthquake followed by tsunami (called Tohoku Earthquake) which killed 25,000 people, 50,000 people missing and made 250000 people homeless and preliminary loss of lives and properties worth of $\$ 310$ billion dollars. The severity of the disaster was beyond imagination which caused such big damage of valuable lives and properties. Even as horrific disaster that struck Japan continues to linger in our minds, one cannot but wonder what would happen if a similar disaster were to strike India?

For this reason, community should be more conscious about disaster prevention culture and mitigation. They should be involved in post disaster recovery and reconstruction process for facing the future disasters and mitigate it. Japan Government's initiative and commitment to mobilize local and international community to minimize the damage and loss from Disaster is highly commendable. Japanese experience of disaster management and mitigation and community involvement in the Great Hanshin-Awaji Earthquake had been proven most successful.

Now days, India is also facing such consequences very frequently. Japanese lessons can be helpful to India to overcome with this challenging and vulnerable situation. In this paper we examined the major disaster phenomenon in Japan and India, a comparative study of disaster management system of Japan and India, techniques of community mobilization in Japan for successful implementation of disaster preparedness planning and recovery from post disaster situations. We would like to replicate some experience; we gained from Japan to our country and recommend some suggestions on effective community mobilization in India.

Key words: disaster, prevention, preparedness, response, recovery, mitigation, risk reduction, disaster risk reduction, sustainable development, risk Identification, disaster rehabilitation and reconstruction, calamity.
\end{abstract}

\section{Introduction}

'A disaster is a serious disruption of the functioning of society, causing widespread human, material or environmental losses which exceed the ability of affected society to cope on its own resources.' Source: UNDHA 2001

Natural disaster is something from which there is no escape. It has always been there since the beginning of human civilizations, but their collision on human beings is increasing ever since it has started up. The emergency management program chooses to focus on preparation initiatives rather than mitigation directly (Newton, 1997, p. 226). Natural disasters, despite of the fact that they are similar in nature and intensity, affect the developed and developing countries differently in terms of the damage of property and loss of lives caused. 


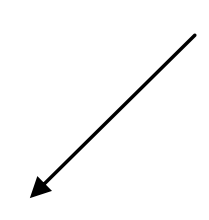

Natural Disasters

* Rain and wind storms

* Floods

* Biological agents

(micro-organisms, insect or vermin infestation)

*Earthquakes

*Volcanic eruptions

*Building deficiencies (structure,

design, environment, maintenance)

Organizing administrative machinery, dealing with disasters, is a vital responsibility of governance (Christoplos, Mitchell and Liljelund (2001); Waugh (2000)). Strong and effective emergency management has been a felt need in all corners of the world (Rosenthal (1988); Sakamura 2001. They discussed vulnerabilities and disaster records of Netherlands and Japan). Responsiveness of governance becomes evident in the manner in which it addresses the crucial task of ameliorating suffering and reducing losses. Public servants have a responsibility for formulating policies and building capacities for dealing with such situations (Waugh (1999)). While the developed countries are well-equipped to survive with them through well functioning of managing the disaster, attentiveness and response mechanisms; the developing countries, poorly equipped in terms of each of the above mentioned considerations, suffer most because of natural disasters. The worst affected in such disasters, in any country, are undoubtedly the poor sections of the society. Not only are they most susceptible to losses from disasters, their ability to recover from the shock brought by a disaster is also the lowest. In the consequences of a disaster, the developing ones face an instant and severe scarcity of resources and lose their contact to livelihood in many cases.

Among all the continents, Asia is considered to be most vulnerable to disasters. During 1991 to 2000, Asia accounted for as much as 83 percent of the population affected by disasters globally. India is highly prone to natural disasters, and the country has experienced very severe natural disasters at regular intervals. Among the various types of natural disasters affecting different parts of the country, floods, cyclones, earthquakes and droughts cause maximum damage to life and property; and heat wave, cold wave, avalanches, landslides, fire are also taking heavy tolls on life and property at regular intervals. The Latur earthquake of 1993-94, the Orissa super cyclone of 1999, the Bhuj earthquake of 2001, and the Tsunami of December 2004, Kashmir Earthquake of 2005, Mumbai Floods of 2005, Uttarakhand Cloud Burst of 2013 are some of the most severe natural disasters that have struck the country in the recent past.

Now, if consider the case of Japan, despite highest disaster preparedness by Japanese Government, on March 11, 2013, northeastern part of Japan has been severely devastated by magnitude 9 earthquake followed by tsunami (called Tohoku Earthquake) which killed 25,000 people, 50,000 people missing and made 250000 people homeless and preliminary loss of lives and properties worth of $\$ 310$ billion dollars. The severity of the disaster was beyond imagination which caused such big damage of valuable lives and properties. Even as horrific disaster that struck Japan continues to linger in our minds, one cannot but wonder what would happen if a similar disaster were to strike India!

For this reason, community should be more conscious about disaster prevention culture and mitigation. They should be involved in post disaster recovery and reconstruction process for facing the future disasters and mitigate it. Japan Government's initiative and commitment to mobilize local and international community to minimize the damage and loss from Disaster is highly commendable. Japanese experience of disaster management and mitigation and community involvement in the Great Hanshin-Awaji Earthquake had been proven most successful.

Our current paper is going to highlight the comparison between Japanese and Indian disaster management and how can we overcome with these problems.

\section{Review of competing theories on Disaster Management}

A very common argument is that socioeconomic conditions and demographics best predict how quickly areas rebuild (Wright et al. 1979; Rubin et al. 1985; Rossi 1993; Berke, Beatley, \& Feagin 1993). Ramakumar (2008) argues that the state of a household before a disaster may be the most important factor in determining its status days, weeks, and years after the event. In a sense, this approach, which argues that disasters merely bring 
to the surface long standing social and economic conditions within the affected area - mirror those made by Alexis de Tocqueville concerning the impact of the French Revolution on post-revolutionary France (1856). Despite the sturm und drang (storm and stress) of the event and its coverage and sensationalism in the popular consciousness, de Tocqueville argues that the Revolution did little to change the dynamics of the old management, many of which continued in post-revolutionary France. Therefore, the disasters, whether it is tsunami or floods or earthquakes, it may simply uncover the inequities, such as poverty and discrimination, which were present before the crisis. For example, poorer residents with part time jobs in secondary fields related to fishing in Tamil Nadu were unemployed for a very long period after the occurrence of tsunami, as officials guided relief towards those who lost "capital," such as boats, nets, and other equipment. Alternatively, poorer households with less education and fewer job skills will have more difficulty securing new livelihoods and the most difficulty in extracting resources from the state and NGOs (Kamel and Loukaitou-Sideris 2004).

Recently theories suggested the role of social networks and ties have come to the fore in explaining the speed of recovery (Nakagawa and Shaw 2004). Social ties can serve as "informal insurance" mechanisms allowing victims to draw upon ready-made support networks. Table 1 summarizes these competing theories.

Table 1: Theories Explaining Recovery Speed

\begin{tabular}{|c|c|c|}
\hline Theory & Logic & Scholarship \\
\hline Financial Aid & $\begin{array}{l}\text { Affected communities with greater support } \\
\text { will recover more quickly }\end{array}$ & Dacy and Kunreuther (1969) \\
\hline Damage Levels & $\begin{array}{l}\text { Areas with greater damage will recover } \\
\text { more slowly }\end{array}$ & Dacy and Kunreuther (1969) \\
\hline Political Institutions & $\begin{array}{l}\text { More efficient, less corrupt agencies within } \\
\text { the state will coordinate a faster recovery }\end{array}$ & Cohen and Werker (2007) \\
\hline Mitigation & $\begin{array}{l}\text { Communities which have previously } \\
\text { encountered disaster will be prepared and } \\
\text { hence recover more quickly from future } \\
\text { crises }\end{array}$ & Eoh (1998), Nakabayashi (2004) \\
\hline Socio-Economic Conditions & $\begin{array}{l}\text { Wealthier neighborhoods and cities will } \\
\text { recovery more rapidly following Disaster }\end{array}$ & $\begin{array}{l}\text { Wright et al. (1979), Rossi (1993), Berke, } \\
\text { Beatley, and Feagin (1993), Ramakumar } \\
(2008)\end{array}$ \\
\hline Civil society & $\begin{array}{l}\text { Better connected communities } \\
\text { neighborhoods will recover faster }\end{array}$ & $\begin{array}{l}\text { Buckland and Rahman (1999); Nakagawa } \\
\text { and Shaw (2004) }\end{array}$ \\
\hline
\end{tabular}

\section{Political Obligation and Institutional Development}

In India, the basic responsibility for undertaking rescue, relief and rehabilitation measures in the event of natural disasters has been that of the State Government concerned. Good governance is seen in the ISDR structure as a key area to promote continued risk diminution efforts. The role of the Central Government has only been supportive, in terms of physical and financial resources and complementary measures in sectors such as transport, warning and inter-State movement of food grains. Relief Manuals and Codes have been available for undertaking emergency operations. The subject of disaster management does not find any specific mention in any of the three lists (Union, State and Concurrent Lists) in the 7th Schedule of Indian Constitution, where subjects under the Central and State Governments as also subjects that come under both are specified. It is the known fact that the States' capability of mobilizing or gathering financial resources has been much less in comparison to that of the Centre, expenditures of the States have always been larger than that of the Centre, the judgment of the Centre with regard to resource mobilization has increased in the era of economic liberalization, and that most of the States have been facing an sensitive fiscal crisis since 1997-98, it is not logical to expect the States to take the major financial burden for the crucial task of managing natural disasters. All through the postIndependence period, States have been held primarily responsible for relief and rehabilitation activities following natural disasters. However, the responsibility for setting up appropriate disaster management mechanisms in the country should lie primarily with the Central Government.

Table I includes a list of core activities to increasingly make certain that disaster risk reduction is the main concern that counts on a strong institutional bases for accomplishment.

Table 1: A framework to guide and monitor Disaster Risk Reduction Thematic area 1: Political Obligation and Institutional Development (Governance) Source: ISDR (2004), Living with Risk, A global review of disaster reduction initiatives

\begin{tabular}{|l|l|l|}
\hline $\begin{array}{l}\text { Thematic areas/ } \\
\text { Components }\end{array}$ & Characteristics & $\begin{array}{l}\text { Criteria for benchmarks } \\
\text { (adapted to megacities context) }\end{array}$ \\
\hline Policy and planning & $\begin{array}{l}\text { Risk reduction as a policy priority } \\
\text { - Risk reduction incorporated into post } \\
\text { disaster reconstruction }\end{array}$ & $\begin{array}{l}\text { - Megacity wide risk reduction } \\
\text { strategy } \\
\text { ・ Disaster reduction in poverty } \\
\text { reduction strategy papers } \\
\text { - Participation in regional and }\end{array}$ \\
\hline
\end{tabular}




\begin{tabular}{|c|c|c|}
\hline & $\begin{array}{l}\text { (poverty eradication, social protection, } \\
\text { sustainable development, climate change } \\
\text { adaptation, desertification, energy, natural } \\
\text { resource management, etc) }\end{array}$ & $\begin{array}{l}\text { international activities, programmes, } \\
\text { networks and structures (including } \\
\text { major conventions) }\end{array}$ \\
\hline $\begin{array}{l}\text { Legal and regulatory } \\
\text { framework }\end{array}$ & $\begin{array}{l}\text { - Laws, acts and regulations } \\
\text { - Codes, standards } \\
\text { - Compliance and enforcement } \\
\text { - Accountability }\end{array}$ & $\begin{array}{l}\text { - Requirement of compliance by law } \\
\text { - Existence and update of codes and } \\
\text { standards } \\
\text { - Existence of systems to ensure } \\
\text { compliance and enforcement }\end{array}$ \\
\hline Resources & $\begin{array}{l}\text { - Resource mobilization and allocation: } \\
\text { financial (innovative and alternative } \\
\text { funding, taxes, incentives), human, } \\
\text { technical, material }\end{array}$ & $\begin{array}{l}\text { - Evidence of budget allocation } \\
\text { - Staffing allocation } \\
\text { - Public-private partnerships }\end{array}$ \\
\hline $\begin{array}{l}\text { Organizational } \\
\text { Structures }\end{array}$ & $\begin{array}{l}\text { - Inter-ministerial, multidisciplinary \& } \\
\text { Multi sectoral approaches } \\
\text { - Implementing and coordinating } \\
\text { mechanisms } \\
\text { - Decentralization, civil society and } \\
\text { community participation, local institutions }\end{array}$ & $\begin{array}{l}\text { - Existence of an administrative } \\
\text { structure responsible for disaster } \\
\text { reduction } \\
\text { - Sectoral Programs } \\
\text { - Consultation with and role for civil } \\
\text { society, NGOs, private sector and } \\
\text { communities } \\
\text { - Existence of "watchdog" groups }\end{array}$ \\
\hline
\end{tabular}

\section{Risk Identification and Assessment}

For any disaster risk reduction process hazards, vulnerabilities and risk identification are the initial stage. This is an area that has been comprehensively developed by multi-disciplinary teams that include hard sciences, social and economic aspects. The opportunity of scrutinizing and forecasting is also considered under this theme based area. By evaluating losses through disaster in a methodical manner and keeping complete record of the social and economic collision of disasters. This will help us to understand where changes for improvement are needed easily.

Table II shows the characteristics and criteria linked to the identification of risk and its assessment.

Table II. A framework to guide and monitor Disaster Risk Reduction

Thematic area 2: Risk Identification and Assessment

Source: ISDR (2004), Living with Risk, A global review of disaster reduction initiatives

\begin{tabular}{|l|l|l|}
\hline $\begin{array}{l}\text { Thematic areas/ } \\
\text { Components }\end{array}$ & Characteristics & $\begin{array}{l}\text { Criteria for benchmarks } \\
\text { (adapted to megacities context) }\end{array}$ \\
\hline $\begin{array}{l}\text { Risk assessment } \\
\text { and data quality }\end{array}$ & $\begin{array}{l}\text { - Hazard analysis: characteristics, impacts, } \\
\text { historical and spatial distribution, multi- } \\
\text { hazard } \\
\text { assessments, hazard monitoring } \\
\text { including of emerging hazards } \\
\text { - Vulnerability and capacity assessment: } \\
\text { social, economic, physical and } \\
\text { environmental, political, cultural factors } \\
\text { - Risk monitoring capabilities, risk maps, } \\
\text { risk scenarios }\end{array}$ & $\begin{array}{l}\text { Vulnerability and capacity indicators } \\
\text { developed and systematically mapped and } \\
\text { recorded. } \\
\text { - Risk scenarios developed and used } \\
\text { Systematic assessment of disaster } \\
\text { risks in development programming }\end{array}$ \\
\hline $\begin{array}{l}\text { Early warning } \\
\text { Systems }\end{array}$ & $\begin{array}{l}\text { - Worecast and prediction } \\
\text { - Response }\end{array}$ & $\begin{array}{l}\text { Unse effectiveness indicators } \\
\text { developed by IATF WG2 (to be } \\
\text { available in October 2003) }\end{array}$ \\
\hline
\end{tabular}

\section{Knowledge Management}

Disaster is a curse which cannot be ignored. But knowledge is the medicine to help ourselves to reduce its effect. Formal education for professionals and capacity building or training for other target groups are explored here as a means for disaster risk reduction. This will help the society to be aware of the uncertainties. At the present scenario, methods of knowledge transfer between researchers and end-users are incompetent to sufficiently transmit knowledge to policy-makers and practitioners. They have also kept knowledge up to the limit of a few authorities. Healthy participation of the society and good technical capabilities to understand hazards and risk improvement are undoubtedly a better approach to reduce the impacts of natural disasters in the long run. A positive involvement of the society, NGO's, the public and private sector, along with the suitable and approachable technologies through economical means such as the electronic media, cellular phones, is a confront still to be deal with. 
Table III. A framework to guide and monitor DRR

Thematic area 3: Knowledge Management

Source: ISDR (2004), Living with Risk, A global review of disaster reduction initiatives

\begin{tabular}{|c|c|c|}
\hline $\begin{array}{l}\text { Thematic areas/ } \\
\text { Components }\end{array}$ & Characteristics & $\begin{array}{l}\text { Criteria for benchmarks } \\
\text { (adapted to megacities context) }\end{array}$ \\
\hline $\begin{array}{l}\text { Information } \\
\text { management and } \\
\text { communication }\end{array}$ & $\begin{array}{l}\text { - Information and dissemination } \\
\text { programmes and channels } \\
\text { - Public and private information systems } \\
\text { (including disaster, hazard and risk } \\
\text { databases \& websites) } \\
\text { - Networks for disaster risk management } \\
\text { (scientific, technical and applied } \\
\text { information, traditional knowledge) }\end{array}$ & $\begin{array}{l}\text { - Documentation and databases on } \\
\text { disasters } \\
\text { - Professionals and public networks } \\
\text { - Dissemination and use of traditional / local } \\
\text { knowledge and practice } \\
\text { - Resource centres and networks, in } \\
\text { particular education facilities }\end{array}$ \\
\hline $\begin{array}{l}\text { Education and } \\
\text { Training }\end{array}$ & $\begin{array}{l}\text { - Inclusion of disaster reduction from } \\
\text { basic to higher education (curricula, } \\
\text { educational material), training of trainers } \\
\text { programs } \\
\text { - Vocational training } \\
\text { - Dissemination and use of traditional/ local } \\
\text { knowledge. } \\
\text { - Community training programmes. }\end{array}$ & $\begin{array}{l}\text { - Educational material and references on } \\
\text { disasters and disaster reduction } \\
\text { - Specialized courses and institutions } \\
\text { - Trained staff } \\
\text { - Evidence of systematic capacity } \\
\text { development programs }\end{array}$ \\
\hline Public awareness & $\begin{array}{l}\text { - Public awareness policy, programmes } \\
\text { and materials } \\
\text { - Media involvement in communicating } \\
\text { risk and awareness raising }\end{array}$ & $\begin{array}{l}\text { - Coverage of disaster reduction related } \\
\text { activities by media } \\
\text { - Public aware and informed } \\
\text { - Visibility of disaster reduction day }\end{array}$ \\
\hline Research & $\begin{array}{l}\text { - Research programs and institutions for } \\
\text { risk reduction } \\
\text { - Evaluation and feedback } \\
\text { - National, regional and international cooperation in } \\
\text { research, science and technology development. }\end{array}$ & $\begin{array}{l}\text { - Existence of a link between science and } \\
\text { policy (evidence-based policy and } \\
\text { policy oriented research) } \\
\text { - Indicators, standards and methodologies } \\
\text { established for risk identification } \\
\text { - Regional an international exchange and } \\
\text { networking }\end{array}$ \\
\hline
\end{tabular}

Statistical Record of the Natural Disasters happened in India at a glance

Data related to human and economic losses from disasters that have occurred between 1980 and 2010.

Natural Disasters from $1980-2010$

Overview:

\begin{tabular}{|l|l|}
\hline No of events & 431 \\
\hline No of people killed & 143039 \\
\hline Average killed per year & 4614 \\
\hline No of people affected & 1521726127 \\
\hline Average affected per year & 49087940 \\
\hline Economic Damage (US\$ X 1,000) & 48063830 \\
\hline Economic Damage per year (US\$ X 1,000) & 1550446 \\
\hline
\end{tabular}

Natural Disaster Occurrence Reported

Average Disaster per year

\begin{tabular}{|l|l|}
\hline drought: & 0.23 \\
\hline Earthquake*: & 0.52 \\
\hline Epidemic: & 1.81 \\
\hline Extreme temp: & 1.23 \\
\hline Flood: & 5.94 \\
\hline Insect infestation: & 0.03 \\
\hline Mass movement dry: & 0.03 \\
\hline Mass movement wet: & 1.10 \\
\hline Volcano: & $\ldots$ \\
\hline Storm: & 2.97 \\
\hline Wildfire: & 0.06 \\
\hline
\end{tabular}

Top 10 Natural Disasters Reported

Affected People

\begin{tabular}{|l|l|l|}
\hline Disaster & Date & Affected \\
\hline Drought & 1987 & $300,000,000$ \\
\hline Drought & 2002 & $300,000,000$ \\
\hline Flood & 1993 & $128,000,000$ \\
\hline Drought & 1982 & $100,000,000$ \\
\hline Drought & 2000 & $50,000,000$ \\
\hline Flood & 2002 & $42,000,000$ \\
\hline
\end{tabular}


Comparative Analysis of Disaster Management between Japan \& India

\begin{tabular}{|l|l|l|}
\hline Flood & 1982 & $33,500,000$ \\
\hline Flood & 2004 & $33,000,000$ \\
\hline Flood & 1995 & $32,704,000$ \\
\hline Flood & 1980 & $30,000,023$ \\
\hline
\end{tabular}

Killed People

\begin{tabular}{|l|l|l|}
\hline Disaster & Date & Killed \\
\hline Earthquake* & 2001 & 20,005 \\
\hline Earthquake* & 2004 & 16,389 \\
\hline Storm & 1999 & 9,843 \\
\hline Earthquake* & 1993 & 9,748 \\
\hline Epidemic & 1984 & 3,290 \\
\hline Epidemic & 1988 & 3,000 \\
\hline Storm & 1998 & 2,871 \\
\hline Extreme temp. & 1998 & 2,541 \\
\hline Flood & 1994 & 2,001 \\
\hline Flood & 1998 & 1,811 \\
\hline
\end{tabular}

Economic Damages

\begin{tabular}{|l|l|l|}
\hline Disaster & Date & Cost (US\$ X 1,000) \\
\hline Flood & 1993 & $7,000,000$ \\
\hline Flood & 2006 & $3,390,000$ \\
\hline Flood & 2005 & $3,330,000$ \\
\hline Earthquake* & 2001 & $2,623,000$ \\
\hline Flood & 2004 & $2,500,000$ \\
\hline Storm & 1999 & $2,500,000$ \\
\hline Flood & 2005 & $2,300,000$ \\
\hline Storm & 1990 & $2,200,000$ \\
\hline Flood & 2009 & $2,150,000$ \\
\hline Storm & 1996 & $1,500,300$ \\
\hline
\end{tabular}

Statistical Record of the Natural Disasters happened in Japan at a glance

Data related to human and economic losses from disasters that have occurred between 1980 and 2010.

Natural Disasters from 1980 - 2010

Overview:

\begin{tabular}{|l|l|}
\hline No of events & 157 \\
\hline No of people killed & 8568 \\
\hline Average killed per year & 276 \\
\hline No of people affected & 3361979 \\
\hline Average affected per year & 108451 \\
\hline Economic Damage (US\$ X 1,000) & 208230800 \\
\hline Economic Damage per year (US\$ X 1,000) & 6717123 \\
\hline
\end{tabular}

Natural Disaster Occurrence Reported

Average Disaster per Year

\begin{tabular}{|l|l|}
\hline Drought: & $\ldots$ \\
\hline Earthquake*: & 1.00 \\
\hline Epidemic: & 0.03 \\
\hline Extreme temp: & 0.10 \\
\hline Flood: & 0.71 \\
\hline Insect infestation: & $\ldots$ \\
\hline Mass movement dry: & $\ldots$ \\
\hline Mass movement wet: & $\ldots .45$ \\
\hline Volcano: & 0.26 \\
\hline Storm: & 2.48 \\
\hline Wildfire: & 0.03 \\
\hline
\end{tabular}

Top 10 Natural Disasters Reported

Affected People

\begin{tabular}{|l|l|l|}
\hline Disaster & Date & Affected \\
\hline Earthquake* & 1995 & 541,636 \\
\hline Flood & 2000 & 360,110 \\
\hline Storm & 2005 & 270,140 \\
\hline Storm & 2004 & 180,050 \\
\hline Storm & 2000 & 180,041 \\
\hline Flood & 1986 & 162,000 \\
\hline Storm & 1982 & 140,000 \\
\hline
\end{tabular}




\begin{tabular}{|l|l|l|}
\hline Storm & 2002 & 100,018 \\
\hline Storm & 1991 & 91,128 \\
\hline Storm & 1990 & 87,778 \\
\hline
\end{tabular}

\section{Killed People}

\begin{tabular}{|l|l|l|}
\hline Disaster & Date & Killed \\
\hline Earthquake* & 1995 & 5,297 \\
\hline Flood & 1982 & 345 \\
\hline Earthquake* & 1993 & 239 \\
\hline Storm & 1983 & 131 \\
\hline Mass mov. wet & 1983 & 117 \\
\hline Earthquake* & 1983 & 102 \\
\hline Storm & 1982 & 100 \\
\hline Storm & 2005 & 100 \\
\hline Storm & 2004 & 89 \\
\hline Storm & 2004 & 88 \\
\hline
\end{tabular}

\section{Economic Damages}

\begin{tabular}{|l|l|l|}
\hline Disaster & Date & Cost (US\$ X 1,000) \\
\hline Earthquake* & 1995 & $100,000,000$ \\
\hline Earthquake* & 2004 & $28,000,000$ \\
\hline Earthquake* & 2007 & $12,500,000$ \\
\hline Storm & 1991 & $10,000,000$ \\
\hline Storm & 2004 & $9,000,000$ \\
\hline Flood & 2000 & $7,440,000$ \\
\hline Storm & 1999 & $5,000,000$ \\
\hline Storm & 1990 & $4,000,000$ \\
\hline Storm & 1998 & $3,000,000$ \\
\hline Storm & 2006 & $2,500,000$ \\
\hline
\end{tabular}

\section{Recovery speed after the disasters:}

Due to unavailability of data we have concise our studies to only few examples of destruction. Let us consider various examples in case of Japan and India.

\section{In case of Japan:}

Japan is located along the northwestern Pacific Rim and the so called "Ring of Fire" where many volcanoes and active earthquakes are frequently encountered. At 5:46 a.m. on January 17, 1995, the Kobe Earthquake struck Japan. The damage caused by the Kobe Earthquake was the death and missing toll stands at 6,437 persons and total monetary loss for Hyogo and surrounding areas stands around 10 trillion yen. More than 80,000 houses were lost and many parts of the urban infrastructure such as express way, bridges, port, and railway facilities were heavily damaged. Recovery of life line and other urban functions was accomplished relatively quickly (electricity 6 days, telephone 14 days, gas 84 days, water 90 days, sewers 93 days). But reconstruction of industry and housing took longer.

To cite another example, let us consider the Chuetsu Earthquake that occurred after the floods of July 13 and the heavy rain of Typhoon no. 23. This has worsened the conditions. This had loosened the ground, and aftershocks continued for a long time afterwards. Immediately after the earthquake, some communities were cut off due to damaged roads. Evacuation of victims was therefore difficult and delivery of emergency supplies and life line services were delayed.

Repair of roads used to supply daily necessities was therefore prioritized in order to quickly reestablish life lines.

JAPAN is "open for business" and "recovering at surprising speed," from the earthquake that devastated the country on March 11, Takeaki Matsumoto, the country's foreign minister, wrote in International Herald Tribune:

"If you imagine that the whole of Japan is covered by debris that is completely wrong. Most of Japan remains unharmed by the disaster, and the streets have leapt back to life. The major highway that runs through the most affected Tohoku region was reopened only two weeks after the earthquake. The Shinkansen, the bullet train that connects Tokyo and Tohoku region, became fully operational again on April 29."

The Democracy in America surveyed the academic research on economic recoveries in the wake of disasters. Here's what they found:

"On the whole, the disaster lit says that the growth effect of disasters depends. Poor countries with weak institutions rocked by calamity may lack the material resources and organizational wherewithal to get back to the status quo ante, in which case the disaster is likely to have profoundly negative long-term effects. (Think Haiti.) As one would expect, rich countries with high-quality institutions and populations with high levels of 
human and social capital recover more quickly, and are most likely to intelligently allocate resources toward improvements over lost capital stock and infrastructure. (Think Japan.) But, of course, recovery from a disaster that kills a huge number of highly-skilled people cannot be accomplished by simply replacing the dead with newer, more highly-skilled models. And, not surprisingly, the scale of the disaster matters. The bigger the human and economic loss, the longer it takes to return back to trend."

"Return to trend economic growth does not compensate for the direct human and economic loss created by the disaster. In the case of Japan, the final toll will be immense. The unofficial death toll is up to 10,000, and more than 15,000 people remain unaccounted for. Economists at Barclays have estimated the loss at 15 trillion yen, or about \$186 billion - about 3\% of Japanese GDP. And the costs of the ongoing knock-on disaster at the Fukushima Daiichi nuclear plant remain unclear. This is horrific pure loss at a sickening scale. There is no silver lining in this."

(Source: The Economist)

\section{In case of India:}

The world has moved on to other preoccupations leaving the 2004 Indian Ocean Tsunami far behind. But the affected countries continue to struggle, and the recovery will still take many years. Further, heavy rain falls and their impact worsened by deforestation, led to the death of so many people, with many others forced from their homes. The massive earthquake in the Indian Ocean, off the coast of the Indonesian island Sumatra, on December 26, 2004 triggered a series of lethal tsunamis that hit the coastal regions of Indonesia, Thailand, Malaysia, Bangladesh, India, Sri Lanka, and Maldives in South/ South-east Asia and the coasts of Somalia, Kenya and Tanzania in eastern Africa. The combined death toll in this unprecedented disaster was above 2, 30,000 even by conservative estimates and over 10 lakh people in these countries were left homeless. In India, the tsunami caused devastation in the coastal areas of three southern States, Andhra Pradesh, Tamil Nadu and Kerala, and in the Union Territories of Andaman \& Nicobar Islands and Pondicherry.

Since the Government apparatus in India had never recognized the threat of a tsunami of such a huge magnitude, pre-disaster mitigation and preparedness measures for this disaster were almost entirely non-existent. Consequently, the devastation caused by the tsunami in the affected areas in India, especially in Andaman \& Nicobar Islands, Pondicherry and the coastal districts of Tamil Nadu were enormous. In Tamil Nadu, the areas of Nagapattinam, Cuddalore, Kanyakumari, Chennai, Villupuram, Tuticorin and Tirunelveli were the worst hit. While most tsunami-affected territories have re-emerged physically, if not psychologically better, not everywhere has recovered at the same pace, including India's Tamil Nadu.

"What is bad is that in the villages on the seashore there has been little clean-up. We can still find boats left five years on which had been washed up and have not been cleaned up. It's more than an eyesore," said Bhatkher Solomon, chief executive officer of the NGO Development Promotion Group.

Some observers say that only about one third of the reconstruction aid that was promised after the tsunami which took place in December 2004 has actually been distributed, and a large portion of the amount has been wasted due to corruption, mismanagement and unnecessary duplication of aid efforts. As a result, hundreds of tsunami survivors continue to wait for permanent homes.

The key propositions for BUILDING BACK BETTER, in some report, Bill Clinton, the UN Special Envoy for Tsunami Recovery, points to "major achievements" such as the approximately 1,50,000 houses that have been built, and the speedy re-enrollment of children in schools after the disaster. But among the ten "key lessons learned" presented in the report, the following in particular have yet to be translated into reality on the ground:

- Governments, donor and aid agencies must recognize that families and communities drive their own recovery.

- Recovery must promote fairness and equity

- Governments must be better prepared for future disasters

- Local governments must be empowered to manage recovery efforts, and donors must devote greater resources to strengthening government recovery institutions

- Agency partnerships must efficiently deliver to those in need without "rivalry and unhealthy competition"

- Good recovery must reduce risks and build resilience in communities.

\section{Measures taken to decrease the impact of Natural Disaster by Japan}

In August 2012 the International Labour Organization started a technical cooperation project "Dissemination of Employment and Labour Measures for Recovering from the Great East Japan Earthquake as International Public Resources", supported by the Government of Japan. The project aims to collect and publicize lessons learnt and good practices related to employment and labour measures, taken from the reconstruction process. These will form the basis of a report that will be presented to a conference to be held in Japan in 2014. 
This was one of its own kind and first technical cooperation project which has been implemented in Japan, and in March 2013, as part of a project expert group meeting, seven experts from Government's, workers' and employers' organizations visited Kamaishi City, to see how one of the places most relentlessly affected by the tsunami was recovering. The experts, from Bangladesh, Cambodia, Indonesia, Malaysia, Pakistan and the Philippines, met the people who somehow survived from the terrific disaster hit. They were running small and medium size businesses. There was a complete social protection mechanism in place where the disaster hit. The government was able to use existing measures to extend employment and livelihood support to those affected by the disaster. Without these existing systems, the recovery efforts would have taken much longer and cost more as it usually happens with the developing nations.

The government was also quick to design and implement nationwide disaster response measures for employment protection and creation. The five-year "Japan as One" Work Project, launched in April 2011, created 200,000 short-term jobs and 500,000 mid-term jobs to long-term jobs. The private sector was also quick to activate support. Some retail companies opened new branches in disaster-affected communities in order to create employment opportunities. The ILO will continue collecting lessons and good practices from the recovery process and disseminate them at a conference in Japan in 2014.

\section{Measures taken to decrease the impact of Natural Disaster by India}

Humans have managed disasters and an overview of our past experiences shows that management of disasters is not a new concept. For example, in ancient India, droughts were effectively managed through conventional water conservation methods, which are still in use in certain parts of the country - like Rajasthan. Local communities have devised indigenous safety mechanisms and drought-oriented farming methods in many parts of the country.

The late 1990s and the early part of this century marked a break point in Disaster Management in India. The Orissa Super Cyclone and the Gujarat Earthquake taught the nation a tough lesson. A welcome step in this direction was setting up of a High Powered Committee on Disaster Management in 1999, which submitted its report in 2001. An important recommendation of the committee was that at least 10 percent of plan funds at the national, state and district levels be earmarked and apportioned for schemes that specifically address areas such as prevention, reduction, preparedness and mitigation of disasters. Also for the first time in the planning history of India, planners devoted a separate chapter titled 'Disaster Management: The development perspective' in the tenth five-year plan document (Planning Commission, 2002).

More recently, several institutions with a focused authorization on disaster management have come up in various parts of the country. The Ministry of Home Affairs (Disaster Management Division), National Institute for Disaster Management (New Delhi), Gujarat State Disaster Management Authority (GSDMA), Orissa State Disaster Management Authority (OSDMA), Disaster Mitigation Institute (Ahmedabad) can be seen as initiatives taken in the right direction.

There has also been a determined effort on the part of the state to mainstream Disaster Mitigation initiatives in Rural Development schemes. One of its example is the coordination between the Ministry of Rural Development and the Ministry of Home Affairs, which is now the nodal ministry for coordination of relief and response and overall natural disaster management, for changing the guidelines of schemes such as Indira Awas Yojna (IAY) and Sampoorn Grameen Rojgar Yojna (SGRY) so that the houses constructed under IAY or school buildings/community buildings constructed under SGRY are earthquake/cyclone/flood resistant.

World Development Report (IFRCRC, 2001) categorizes natural disasters into hydro meteorological (earthquakes, volcanic eruptions, etc) and geophysical (landslides, droughts, etc) categories. The scope of unnatural disasters broadly encompasses conflicts, civil strife, riots and industrial disasters.

In the past decade (1991-2000), natural disasters have killed 66, 59,598 people, accounting for 88 percent of all deaths due to disasters. Similarly, unnatural disasters have killed 86,923 people during the decade. Nearly two-thirds of the people killed in these disasters hail from developing countries like India, with only four percent of the casualties being reported from highly developed countries (IFRCRC, 2001).

Not like Japan but then also India is considered as the world's most disaster prone country. Like many other countries in this region, India is beleaguered by various kinds of natural disasters every year, such as floods, drought, earthquakes, cyclones, cloud bursts and landslides. Millions of people are affected every year and the economic losses caused by natural disasters amount to a major share of the Gross National Product (GNP). Every year, huge amount of resources are mobilized for rescue, relief and rehabilitation works following natural disaster occurrences and after these efforts also, leaving behind new count to the poverty number.

In India, a closer analysis of what converts a natural event into a human and economic disaster discloses that the elementary problems of development that the country faces are the very same problems that contribute to its susceptibility to the disastrous effects of natural hazards. The principal causes of susceptibility include quick and uncontrolled urbanization, doggedness of widespread urban and rural poverty, and dreadful 
conditions of the environment resulting from the mismanagement of natural resources, inefficient public policies, and misguided investments in infrastructure.

Development and disaster-related policies have under estimated the investment in natural hazard prevention and mitigation and have largely focused on emergency response.

Here people are getting help in the form of money, food, clothes, etc., but rehabilitation is still a serious issue. It takes a prolonged time. As India being a developing country faces a serious problem of unemployment and natural disaster is simply adding up number to the unemployment list.

\section{Comparison between India and Japan}

One Year after the Disaster...

\begin{tabular}{|l|l|l|l|}
\hline Case & Business sector & Shops/ schools & Housing \\
\hline Kobe, Japan & $\begin{array}{l}80 \% \text { exports, 90\% } \\
\text { manufacturing } \\
\text { restored }\end{array}$ & $\begin{array}{l}80 \% \text { shops, majority } \\
\text { of schools reopened }\end{array}$ & $\begin{array}{l}\text { Close to } 85 \% \text { in } \\
\text { permanent housing }\end{array}$ \\
\hline Tamil Nadu, India & $\begin{array}{l}\text { Almost all } \\
\text { fishermen back at } \\
\text { work }\end{array}$ & $\begin{array}{l}\text { Old schools rebuilt, } \\
\text { new schools being } \\
\text { created }\end{array}$ & $\begin{array}{l}50 \% \text { housing } \\
\text { restored }\end{array}$ \\
\hline
\end{tabular}

\section{Challenges for the future}

Prevention, mitigation, preparedness and relief are four elements, which add to and gain from the accomplishment of sustainable development policies. The Yokohama Strategy, originating from the international decade for natural disaster reduction in May 1994, highlights that disaster prevention, mitigation and preparedness are better than disaster-response in achieving the goals and objectives of susceptibility diminution.

The Government of India has considered mitigation and prevention as fundamental components of its development strategy. The Tenth Five Year Plan emphasizes the fact that "development cannot be sustainable without mitigation being built into the development process."

The need of the hour is to prepare a multi-branched approach for total disaster management comprising prevention, preparedness, response and recovery, and initiating development efforts towards risk reduction and mitigation. As per Luan, the countries in the Asia-Pacific region should establish a regional co-ordination mechanism for space-technology based disaster mitigation and strengthen co-operation, he further said that they also need to set up an all-weather and all-time comprehensive space-based disaster mitigation system and share the information.

A realistic attitude to reduce the effect of disasters in the country requires a more extensive approach that comprises both pre-disaster risk reduction and post-disaster recovery. It is framed by new policies and institutional arrangements that support effective action. This kind of attitude should involve the following set of activities:

1. Identification: Risk analysis is to be done in order to identify the kinds of risks faced by people.

2. Prevention and mitigation: It is to be done in order to address the structural sources of susceptibility.

3. Risk transfer: Risk transfer is helpful in spreading the financial risks over time and among different factors.

4. Emergency preparedness and response: This will enhance a country's readiness to manage swiftly and efficiently with an urgent situation.

5. Post disaster rehabilitation and reconstruction: This is the final step to support successful healing and to safeguard against future disasters.

\section{Disaster Plan}

Disaster Plan involves four phases:

1. Prevention

2. Preparedness

3. Response

4. Recovery

\section{Phase 1: Prevention}

1. Identify and minimize the risks posed by the building, its equipment and fittings, and the natural hazards of the area.

2. Carry out a building inspection and alter factors which constitute a potential hazard.

3. Establish routine housekeeping and maintenance measures to withstand disaster in buildings and surrounding areas.

4. Install automatic fire detection and extinguishing systems, and water-sensing alarms.

5. Take special precautions during unusual periods of increased risk, such as building renovation. 
6. Make special arrangements to ensure the safety of library or archival material when exhibited.

7. Provide security copies of vital records such as collection inventories, and store these off-site.

8. Protect computers and data through provision of uninterrupted power supply.

9. Have comprehensive insurance for the library or archives, its contents, the cost of salvage operations, and potential replacement, re-binding and restoration of damaged materials.

\section{Phase 2: Preparedness}

1. Getting ready to cope.

2. Develop a written preparedness, response and recovery plan.

3. Keep the plan up-to-date, and test it.

4. Keep together supplies and equipments required in a disaster and maintain them.

5. Establish and train an in-house disaster response team. Training in :

a. disaster response techniques,

b. Identification and marking on floor-plans and enclosures of irreplaceable and important material for priority salvage.

6. Prepare and keep an up-to-date set of documentation including :

a. Building floor-plans, with locations of cut-off switches and valves.

b. Inventory of holdings, with priorities for salvage marked on floor-plans.

c. List of names, addresses, and home telephone numbers of personnel with emergency responsibilities.

d. List of names, addresses, and home telephone numbers of the in-house disaster response team.

e. List of names, addresses and home telephone numbers of trained conservators with experience in salvaging water-damaged materials, resource organisations, and other facilities able to offer support in the event of a disaster.

f. List of disaster control services, in-house supplies and equipment, and in any central store, including locations and names of contacts with home telephone numbers.

g. List of suppliers of services and sources of additional equipment and supplies, including names of contacts and home telephone numbers.

h. Arrangements made to access freezing facilities.

i. $\quad$ Arrangements for funding emergency needs.

j. Copies of insurance policies.

k. Salvage procedures.

7. Distribute the plan and documentation to appropriate locations on- and off-site.

8. Institute procedures to notify appropriate people of the disaster and assemble them rapidly.

\section{Phase 3: Response}

When disaster strikes

1. Follow established emergency procedures for raising the alarm, evacuating personnel and making the disaster site safe

2. Contact the leader of the disaster response team to direct and brief the trained salvage personnel

3. When permission is given to re-enter the site, make a preliminary assessment of the extent of the damage, and the equipment, supplies and services required.

4. Stabilize the environment to prevent the growth of mould.

5. Photograph damaged materials for insurance claim purposes.

6. Set up an area for recording and packing material which requires freezing, and an area for air-drying slightly wet material and other minor treatment.

7. Transport water-damaged items to the nearest available freezing facility.

\section{Phase 4: Recovery}

Getting back to normal

1. Establish a programme to restore both the disaster site and the damaged materials to a stable and usable condition.

2. Determine priorities for restoration work and seek the advice of a conservator as to the best methods and options, and obtain cost estimates.

3. Develop a phased conservation programme where large quantities of material are involved.

4. Discard items not worth retaining, and replace or re-bind items not justifying special conservation treatment.

5. Contact insurers.

6. Clean and rehabilitate the disaster site.

7. Replace treated material in the refurbished site. 
8. Analyze the disaster and improve the plan in the light of experience.

Source: www.webworld.unesco.org/safeguarding/en/pdf/txt_sini.pdf

\section{Suggestions}

Disaster management is fundamentally a self-motivated process. It involves many organizations, which must work together to prevent, mitigate, prepare for, respond to and recover from the effects of disaster. Disaster management would therefore include immediate response, recovery, prevention, mitigation, preparedness and this way the cycle goes on.

The subject of disaster management is not mentioned in any of the three lists in the Seventh Schedule of the Indian constitution, where subjects under the Central and State governments are specified. In the postindependent India, a journey through the five-year plans points to the fact that the understanding of disasters was to mitigate droughts and floods; schemes such as the Drought Prone Area Program (DPAP), Desert Development Program (DDP), National Watershed Development Project for Rain fed Areas (NWDPRA) and Integrated Water Development Project (IWDP) are examples of this conventional paradigm (Planning Commission, 2002).

Disasters and their management generally get discussed in their aftermath but practically it should result in planning and preparing the strategy to tackle and mitigate disasters in a responsible and effective manner. Disasters, both natural and unnatural, are macro level events or processes, which induce disturbances and confusion for a prolonged life-threatening environment for a community.

\section{Conclusion}

There has been a rise in natural disasters in recent years that have put under pressure both wealthy and poorer nations, resulting in humanitarian crises of immense proportions. These incidents have been a serious beginning to international bodies. The adoption of the International Strategy for Disaster Reduction (ISDR) 2000, the World Conference on Disaster Reduction 2005, the Hyogo Framework for Action 2005-2015, and the recent 2010-2011 World Disaster Reduction Campaign are efforts in that direction.

From the above paper, it will be difficult to say that the developing nations are far behind the lag. We have to adapt the new strategies and policies so that we can face the problems more confidently and positively. Natural disaster is a threat which cannot be prevented, but measures can be taken to do away with or reduce the possibility of its impact on the society, economy and environment. Loss of lives cannot be recovered but apart from these human losses other losses can be secured.

Thus, as regards management of natural disasters, at most levels, focus of the Government machinery in India has been on rescue and relief operations only, while in case of Japan it is beyond that. In India, the Government machinery lacks proper training in disaster management and it is poorly equipped to undertake natural disasters through effective mitigation and preparedness measures. While the fundamental aspects of managing with natural disasters, like, disaster mitigation and preparedness, have always been ignored, even the post-disaster response of the state through rescue, relief and rehabilitation measures have been found insufficient most of the time.

Recently, activities related to disaster management at the planning and policy-making level in the country have expanded considerably. On the other hand, only few would disagree that the susceptibility of the country to losses from natural disasters has reduced over this period of time.

From the above things it is very clear that it is not a one man show, but the whole nation will have to stand for the victims all together. Merely donating money, clothes, food, etc. is not the only thing to be done, but it is beyond that. We cannot fight with the disasters until and unless we find the difference between 'empathy' and 'sympathy'. One should have empathy in order to help the nation to recover the earliest.

\section{References}

[1]. Aguirre, Benigno. 1988. "Feedback from the Field. The Lack of Warning Before the Saragoso Tornado." International Journal of Mass Emergencies and Disaster 6(1): 6574.

[2]. Albala-Bertrand, J. M. (1993). Political Economy of Large Natural Disasters: With Special Reference to Developing Countries. Clarendon Press: Oxford.

[3]. Aldrich, Daniel P. (2008). Site Fights: Divisive Facilities and Civil Society in Japan and the West. Ithaca and London: Cornell University Press.

[4]. Alexander, David. 1991. "Natural disasters: a framework for research and teaching." Disasters 15: 209-26

[5]. Bill, James A. and Robert L. Hardgrave, Jr. 1981. Comparative Politics: The Quest for Theory. University Press of America: Lanham, MD.

[6]. Birkland, Thomas A. 1996. "Natural Disasters as Focusing Events: Policy Communities and Political Response." International Journal of Mass Emergencies and Disasters 14 (2): 221-243.

[7]. Britton, Neil. "National Planning and Response: National Systems" in Handbook of Disaster Research. Disaster Research Center: University of Delaware.

[8]. Cochrane, Hal. 2004. "Economic loss: myth and measurement" Disaster Prevention and Management 13: 290-296. 
[9]. Comfort, L. 1996. "Self-organization in disaster response: the Great Hanshin, Japan Earthquake of January 17, 1995." Quick Response Report No. 78, Natural Hazards Center, University of Colorado, Boulder, CO.

[10]. Comfort, L. et.al. 1999. "Reframing Disaster Policy: The Global Evolution of Vulnerable Communities." Environmental Hazards 1: $39-44$

[11]. Fothergill, Alice, Enrique G.M. Maestas, and JoAnne DeRouen Darlington. 1999. "Race, Ethnicity, and Disasters in the United States: A Review of Literature." Disasters. 23(2):156-173

[12]. Gupta A; "Information Technology and Natural Disaster Management in India"; www.gisdevelopment.net

[13]. International Federation of Red Cross and Red Crescent Societies (2001); "World Disaster Report - Focus on reducing risk"; IFRCRCS; Geneva

[14]. McEntire, David A. 2004. "Development, Disasters and Vulnerability: A Discussion of Divergent Theories and the need for their integration." Disaster Prevention and Management 13 (3): 193-198.

[15]. McEntire, David A. 2004. "Tenets of Vulnerability: An Assessment of a Fundamental Disaster Concept." Journal of Emergency Management 2 (2): 23-29.

[16]. McEntire, David and Christopher Fuller. 2002. "The need for a holistic theoretical approach: an examination from the El Niño disasters in Peru." Disaster Prevention and Management. 11(2): 128-140.

[17]. Mileti, D.S., Darlington, J.D., Passaini, E., Forest, B.C., and Myers, M.F. 1995. "Toward an integration of natural hazards and sustainability", Environmental Professional 17:117-26.

[18]. Nakagawa, Yuko and Shaw, Rajib.: A Comparative Study of Urban Reconstruction Processes After Earthquakes in Turkey, Taiwan, and Japan. Tokyo, Japan: Graduate School of Urban Science, Tokyo Metropolitan University, pp. 5 -14. (2004).

[19]. Planning Commission (2002); “Tenth Five Year Plan (2002-2007) - Vol.1”; Planning Commission, Government of India; New Delhi.

[20]. Public Policy towards Natural Disasters in India, CBGA, 2005, http://www.ncasindia.org

[21]. Ramakumar, R. (2008). Contextualizing Disaster Studies: Socioeconomic Vulnerabilities in India. Presentation at Researching Disasters Conference, at Tata Institute, Mumbai, 4 February.

[22]. www.ndmindia.nic.in

[23]. http://www.dnaindia.com/mumbai/1526423/analysis-japans-disaster-management-indias management-disaster

[24]. http://www.guardian.co.uk/global-development/datablog/2011/mar/18/world-disasters-earthquake-data

[25]. http://en.wikipedia.org/wiki/Natural_disasters_in_Japan 